\title{
APPLICATION OF IONIC LIQUIDS FOR SEPARATION OF PROPYNE FROM PROPYLENE: SOLUBILITY AND SELECTIVITY STUDIES
}

\author{
Jelliarko Palgunadi1 ${ }^{1,}$, Antonius Indarto ${ }^{2,}{ }^{*}$, Haryo Winoto ${ }^{2}$, and Hoon Sik Kim ${ }^{1}$ \\ ${ }^{1}$ Green Chemistry Lab, Department of Chemistry, Kyung Hee University \\ Hoegi-dong Dongdaemun-gu, Seoul 130-701, Rep. of Korea \\ 2Department of Chemical Engineering, Faculty of Industrial Technology \\ Institut Teknologi Bandung, Jalan Ganesha 10 Bandung 40132 Indonesia \\ E-mail: jelliarko@gmail.com; Antonius.indarto@che.itb.ac.id
}

\begin{abstract}
Separation or removal of propyne from propylene, generated by naptha cracking process, is one of the most important processes in petrochemical industries because ppm level of propyne contained in feed olefins can serve as catalyst poisons in the polymerization of olefins. Recently, room temperature ionic liquids (RTILs) were introduced as novel solvents for the separation of various gases and hydrocarbons. RTIL is a salt composed of unsymmetrical organic cation and organic/inorganic anion which melts at room temperature. Prior to the decision of material selection for the effective separation of propyne/propylene employing RTIL, solubility behaviors and selectivities of propyne and propylene in various RTILs were investigated. For the solubility of propyne and propylene in 1-R-3-methylimidazolium-based RTILs, solubility measurement, thermodynamic analysis, and computational calculation strongly imply that the solubility of propyne is controlled by a trade-off between a specific solute-solvent interaction (hydrogen bonding of propyne-anion) and non bonding interaction (solubility parameter). In contrast, the solubility of propylene seems to be much strongly dependent on non-bonding interaction (solubility parameter) closely related to the physical attractive forces as suggested by regular solution theory. Thus, to achieve high selectivity of propyne over propylene, a RTIL with smaller-size and stronger hydrogen bonding ability should be employed.
\end{abstract}

Keywords: propyne, propylene, solubility, selectivity, ionic liquids.

\begin{abstract}
Abstrak
Pemisahan senyawa propuna dari propena, yang dihasilkan oleh proses fraksionasi nafta adalah salah satu proses yang paling penting dalam industri petrokimia. Kontaminan propuna yang terkandung dalam umpan olefin dapat menjadi racun katalis dalam proses polimerisasi olefin. Kini cairan ionik temperatur ruang (RTIL) diperkenalkan sebagai pelarut baru untuk pemisahan berbagai gas dan hidrokarbon. RTIL adalah garam yang terdiri dari kation organik dan anion organik/anorganik asimetrik yang meleleh pada suhu kamar. Pemilihan senyawa pelarut RTIL yang tepat untuk pemisahan propuna / propena akan dibahas dalam tulisan ini. Dalam proses pelarutan propuna dalam RTIL berbasis 1-R-3metilimidazolium, pengukuran kelarutan, analisis termodinamika, dan pemodelan mengisyaratkan bahwa kelarutan propuna dikendalikan oleh kompromi antara interaksi spesifik solut-pelarut (ikatan hidrogen propuna-anion) dan interaksi tak mengikat (parameter kelarutan). Sebaliknya, kelarutan propena sangat bergantung pada interaksi tak mengikat (parameter kelarutan) yang erat hubungannya dengan ikatan fisik seperti dipaparkan dalam teori larutan biasa (regular solution theory). Dengan demikian, untuk mencapai selektivitas tinggi terhadap propuna dibandingkan dengan propena, disarankan untuk menggunakan senyawa RTIL dengan ukuran molekul lebih kecil yang memiliki ikatan hidrogen lebih kuat.
\end{abstract}

Kata Kunci: propuna, propena, kelarutan, absorpsi, cairan ionik.

*corresponding authors 


\section{Introduction}

Separation of alkyne compounds from olefin mixtures is important in the purification of olefins used for the polymerization processes (Huang et al., 2007; Bos and Westerterp, 1993) as well as in the production of alkynes as raw materials for many organic syntheses. Olefins are mainly produced by thermal or catalytic cracking of naphtha and gas oils (Downie, 2002; Roberts, 1976). However, thus produced olefins often contain about 2-4\% alkyne compounds (acetylene or propyne), which can serve as catalyst poisons in the olefin polymerization process (Huang et al., 2007).

Presently, the separation of propyne from propylene is accomplished by costly solvent extraction processes using organic solvents such as DMF $\left(N, N^{\prime}\right.$ dimethylformamide) and NMP $(N$ methylpyrrolidinone) (Weissermel and Arpe, 2003). However, this process is disadvantageous in terms of technical and economical aspects, particularly due to the low selectivities of propyne over propylene and also to the significant loss of solvent after multiple operations.

Recently, Room-Temperature Ionic Liquids (RTILs) have been proposed as alternative and green solvents for the liquid extraction of hydrocarbons (Arce et al., 2008). RTIL is a compound composed of entirely ions with melting point or glass transition temperature below $100 \mathrm{C}$ (Pârvulescu and Hardacre, 2007). Due to several outstanding physicochemical properties in compared to common organics such as, negligible vapor pressure, moderate polarity, customized functionality and miscibility, wide liquid range, workable viscosity, and thermal stability, RTILs have been considered as newly potential materials for separation processes (Han and Armstrong, 2007). To investigate the potential application of RTILs for the separation of propyne from propylene, solubility measurements of those hydrocarbons in several RTILs were carried out. Solubility behaviors and selectivities of propyne over propylene in RTILs under study are revealed for the first time.

\section{Experimental Section RTILs synthesis}

Dialkylimidazolium-based RTILs bearing alkylphosphite and dialkylphosphate anion ([RMIM] $\left[\mathrm{RHPO}_{3}\right]$ and $[\mathrm{RMIM}]\left[\mathrm{R}_{2} \mathrm{PO}_{4}\right]$, (where $\mathrm{R}=-\mathrm{CH}_{3},-\mathrm{C}_{2} \mathrm{H}_{5}$, and $-\mathrm{C}_{4} \mathrm{H}_{9}$ ) were prepared from the reaction of 1methylimidazole with the corresponding dialkyl phosphite and trialkyl phosphate, respectively (Kuhlmann et al., 2007). dialkylimidazolium tetrafluoroborate and bis(trifluoromethylsulfonyl)imide are commercially available from Aldrich Co. and were used as received. Dialkylimidazolium alkylsulfates ([RMIM] $\left[\mathrm{RSO}_{4}\right]$, where $\mathrm{R}=-\mathrm{CH}_{3}$, and $-\mathrm{C}_{2} \mathrm{H}_{5}$ ) were prepared by reacting 1 methylimidazole with dialkyl sulfate (Holbrey et al., 2002).

Purities of the RTILs were found to be better than $97 \%$ as deduced from the proton NMR analysis. These ionic liquids were dried at $70 \stackrel{\circ}{ } \mathrm{C}$ under a reduced pressure $(\sim 10$ mbar) at least for $4 \mathrm{~h}$ prior to use. The chemical structures of RTILs used in this study are given in Figure 1.

\section{Solubility measurement}

Low-pressure, individual gas solubility measurements at $313 \mathrm{~K}$ were carried out based on the isochoric saturation method (Jacquemin et al., 2006). Details of the measurement apparatus, technique, data reductions, and thermodynamic analysis are available in the previously published literature (Palgunadi et al., 2009).

\section{Results and Discussion}

Solubility evaluations of ethylene and acetylene in RTILs were performed at pressures close to atmosphere ranging from 10 to $170 \mathrm{kPa}$ and at $313 \mathrm{~K}$ based on a pressure-decay observation.

The solubilization of a solute in a solvent is controlled by two different thermodynamic factors. The first one is the formation of cavities within the solvent to accommodate the solute molecules. The second one is the chemical interaction of the inserted solute molecules with the solvent molecules. The first factor requires energy to break the solvent-solvent interaction. Based on regular solution model, this interaction can be described as Hildebrand solubility parameter or cohesive parameter $(\delta)$. Accordingly, if the first thermodynamic step is dominant in controlling the solubility of gaseous solute, the solubility parameter for solvent $\left(\delta_{1}\right)$ can be used to determine the solubility behavior of a gas. 


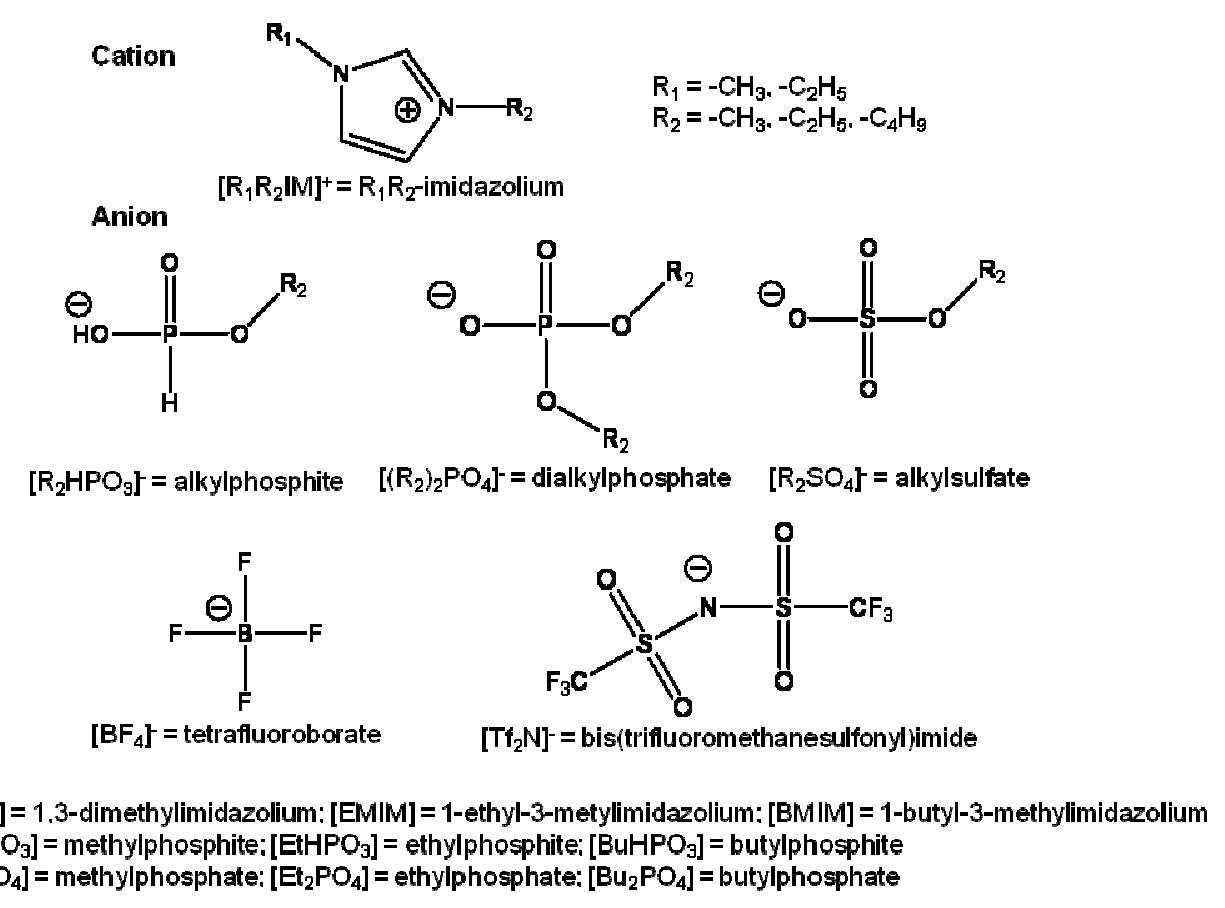

Figure 1. The structures and nomenclature system of RTILs under study

To demonstrate the importance of the first thermodynamic step in solubilization and also to predict the solubility behavior of $\mathrm{CO}_{2}$ and some other gases in imidazolium-based ILs at low pressures, Camper et al. proposed simplified regular solution theory (RST) (Camper et al., 2005). Fundamental aspects and approaches can be found in their recent publications (Camper et al., 2005; Camper et al., 2006). Based on RST, the gas solubility in a physical solvent can be solely determined from solubility parameters $\left(\delta_{\mathrm{i}}\right)$ as long as Henry's law is valid, which means solubility at pressure close to atmosphere.

$$
\ln \left[H_{2.1}\right]=a+b\left(\delta_{1}-\delta_{2}\right)^{2}
$$

In Camper's works (Camper et al., 2006), Kapustin-skii equation was used to estimate the lattice energy density of RTILs and later this value was used to calculate the solubility parameter of RTILs $\left(\delta_{1}\right)$. This approach results in a specific relation of solubility parameter $\left(\delta_{1}\right)$ as a function of molar volume of RTIL (Eq. 2).

$$
\delta_{1} \propto\left(\frac{1}{V_{m}^{4 / 3}}\right)^{1 / 2}
$$

After lumping $\delta_{2}$ into $a$ constant, the combination of Eq. 1 and Eq. 2 gives Eq. 3 and lastly Eq. 4 as the simplified model of RST where $\alpha, \beta$, and $\beta^{*}$ are constants that depend on the temperature and the type of gas.

$$
\begin{aligned}
& \ln \left[H_{2.1}\right]=\alpha+\beta\left(\delta_{1}\right)^{2} \\
& \ln \left[H_{2.1}\right]=\alpha+\left(\frac{\beta^{*}}{V_{m}^{4 / 3}}\right)
\end{aligned}
$$

From Eq. 4, a linear relationship must exist for RST to be valid over the gas-RTILtemperature combination. This relationship also indicates that a solvent with a greater molar volume possesses a smaller solubility parameter and hence a smaller cohesion energy leading to a higher solubility of solute molecules.

Table 1 lists the estimated values of the molar volume of RTILs at room temperature, and Henry's law constants of propylene and propyne. Plots of natural log of Henry's law constant versus inverse molar volume for propylene and propyne in various RTILs are given in Figure 2. It is obvious that a relatively linear trend for propylene as suggested by Eq. 4 is existed implying that the solubility of ethylene is largely controlled by the first thermodynamic factor (non-bonding interaction). In other words, the solubility of propylene is dependent on the solubility parameter of RTIL. Meanwhile, the poorer 
Table 1 Molar Volume of RTILs at Room Temperature, and Henry's Law Constants of Propylene and Propyne (313 K).

\begin{tabular}{|c|c|c|c|c|}
\hline Entry & RTIL & $V_{\mathrm{m}} / \mathrm{mL} \mathrm{mol} \mathbf{m}^{-1}$ & $\mathrm{H}_{2.1} / \mathrm{atm} \mathrm{C}_{3} \mathrm{H}_{6}$ & $\mathrm{H}_{2.1} /$ atm $\mathrm{C}_{3} \mathrm{H}_{4}$ \\
\hline 1 & {$[\mathrm{DMIM}]\left[\mathrm{MeHPO}_{3}\right]$} & 156.5 & 186.1 & 11.3 \\
\hline 2 & {$[\mathrm{EMIM}]\left[\mathrm{MeHPO}_{3}\right]$} & 170.7 & 117.0 & 8.7 \\
\hline 3 & {$[\mathrm{EMIM}]\left[\mathrm{EtHPO}_{3}\right]$} & 187.9 & 110.1 & 7.6 \\
\hline 4 & {$[\mathrm{BMIM}]\left[\mathrm{BuHPO}_{3}\right]$} & 254.7 & 37.2 & 5.9 \\
\hline 5 & {$[\mathrm{DMIM}]\left[\mathrm{Me}_{2} \mathrm{PO}_{4}\right]$} & 177.5 & 137.4 & 8.6 \\
\hline 6 & {$[\mathrm{EMIM}]\left[\mathrm{Me}_{2} \mathrm{PO}_{4}\right]$} & 192.7 & 100.1 & 7.1 \\
\hline 7 & {$[\mathrm{EMIM}]\left[\mathrm{Et}_{2} \mathrm{PO}_{4}\right]$} & 232.8 & 49.6 & 5.8 \\
\hline 8 & {$[\mathrm{BMIM}]\left[\mathrm{Bu}_{2} \mathrm{PO}_{4}\right]$} & 327.7 & 24.6 & 4.6 \\
\hline 9 & {$[\mathrm{DMIM}]\left[\mathrm{MeSO}_{4}\right]$} & 156.6 & 241.5 & 17.1 \\
\hline 10 & {$[\mathrm{EMIM}]\left[\mathrm{EtSO}_{4}\right]$} & 192.3 & 112.8 & 9.4 \\
\hline 11 & {$[\mathrm{EMIM}]\left[\mathrm{MeSO}_{4}\right]$} & 170.9 & 173.7 & 13.1 \\
\hline 12 & {$[\mathrm{BMIM}]\left[\mathrm{MeSO}_{4}\right]$} & 205.8 & 97.9 & 9.2 \\
\hline 13 & {$[\mathrm{EMIM}]\left[\mathrm{BF}_{4}\right]$} & 158.2 & 168.2 & 14.6 \\
\hline 14 & {$[\mathrm{BMIM}]\left[\mathrm{BF}_{4}\right]$} & 187.1 & 88.7 & 9.7 \\
\hline 15 & {$[\mathrm{EMIM}]\left[\mathrm{Tf}_{2} \mathrm{~N}\right]$} & 258.4 & 39.7 & 8.5 \\
\hline
\end{tabular}

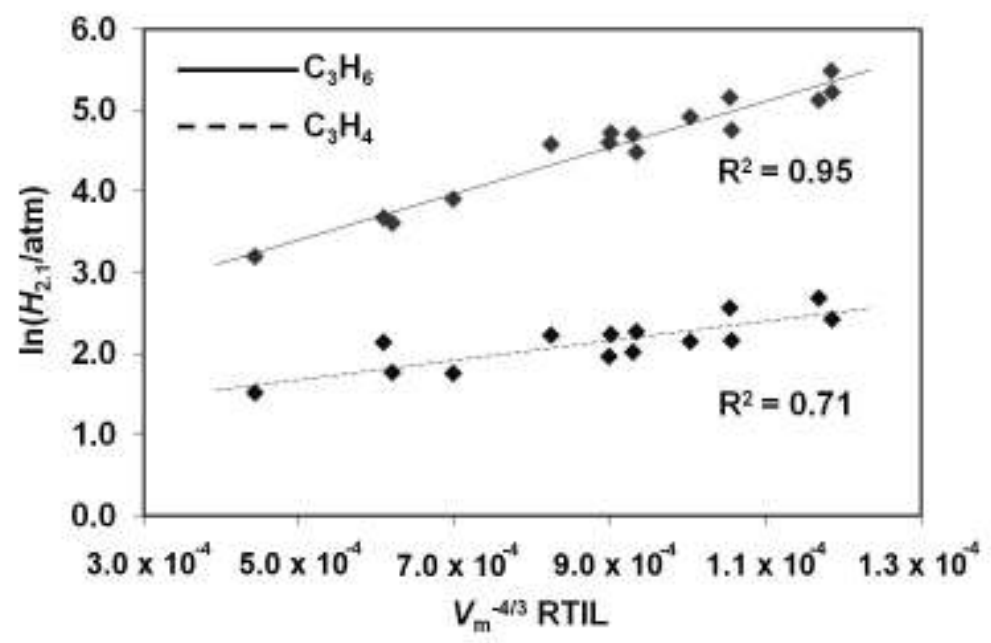

Figure2. Solubility of propylene and propyne in correlation with the molar volume of RTIL (313 K).
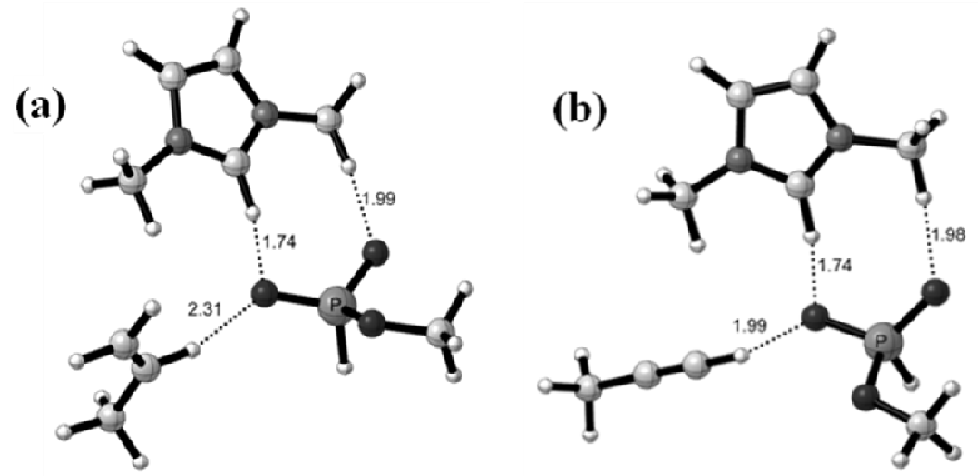

Figure 3. Optimized geometry showing the molecular interaction between propylene (a) or propyne (b) and [DMIM] $\left[\mathrm{MeHPO}_{3}\right],\left(\Delta H \mathrm{C}_{3} \mathrm{H}_{6}-\mathrm{RTIL}=-0.13 \mathrm{~kJ} \mathrm{~mol}^{-1} ; \Delta H \mathrm{C}_{3} \mathrm{H}_{4}-\mathrm{RTIL}=-\mathbf{1 0 . 5 0} \mathrm{kJ}\right.$ mol-1 $^{-1}$. All values are in Angstrom unit. 
linear trend observed for propyne might indicate that the second thermodynamic step corresponding to a specific molecular interaction or a solute-solvent complexation also plays important role in controlling the solubility of propyne.

$\mathrm{Ab}$ initio molecular calculations using Gaussian 03 package software were carried out to investigate the mode of cross solutesolvent interactions possibly existing in the systems. Figure 3 shows the optimized geometries of propylene and propyne when interacting with [DMIM] $\left[\mathrm{MeHPO}_{3}\right]$.

Figure 3 clearly shows that propylene as well as propyne is located close to the anion of the RTIL. The acidic protons of those hydrocarbons $\left(\mathrm{H} \mathrm{sp}^{2}\right.$ in propylene and $\mathrm{H} \mathrm{sp}$ in propyne) interact and form hydrogen bonding with the most basic site of the anion, the oxygen atom. The figure also indicates that the $\mathrm{H}$-bond of propyne-anion is much shorter than that of propylene-anion implying stronger interaction. In addition, the enthalpies of interaction were calculated around $-10.50 \mathrm{~kJ} \mathrm{~mol}^{-1}$ and $0.13 \mathrm{~kJ} \mathrm{~mol}^{-1}$ for $\mathrm{C}_{3} \mathrm{H}_{4}-\left[\mathrm{MeHPO}_{3}\right]^{-}$and for $\mathrm{C}_{3} \mathrm{H}_{6}-\left[\mathrm{MeHPO}_{3}\right]^{\text {; }}$ respectively, again suggesting that propyneanion interaction is much stronger.

The presence of chemical associations and the strength of the interactions in the absorption phenomenon can also partly be seen from the thermodynamic magnitude of enthalpy. If specific interactions play dominantly in determining the solute solubility, it can be expected that the more basic the ionic liquid is, the stronger the $\mathrm{H}$ bond interaction is. Thus, a linear trend between the solubility and enthalpy of absorption may present. Figure 4 reveals that a regular correlation between the solubility of propyne or propylene versus enthalpy of absorption does not exist. It suggests that the solubilities of those hydrocarbons are not solely dependent on the specific H-bond interaction. However, despite the fact that enthalpy of absorption is not the major determining factor for propyne solubility, a RTIL holding more basic anion tends to absorb more propyne (i.e. [RMIM] $\left[\mathrm{RHPO}_{3}\right]$ and [RMIM] $\left[\mathrm{R}_{2} \mathrm{PO}_{4}\right]$ ).

Absorption selectivity is an important consideration prior to the development of process design. To gain understanding on the selectivity behavior with regard to the RTIL's property, ideal absorption selectivities of propyne over propylene (expressed as the inverse ratio of Henry's constants of propyne over propylene) versus molar volume of RTILs are plotted in Figure 5. As can be seen from the figure, a regular trend does exist where it shows that smaller molar volume of RTIL lead $s$ to higher propyne absorption selectivity. Combining the data trend in Figure 4 and the data in Table 1, it can be deduced that the highest selectivity of propyne absorption over propylene may be achieved with the use of the smallest RTIL containing basic anion, such as [DMIM] $\left[\mathrm{MeHPO}_{3}\right]$.

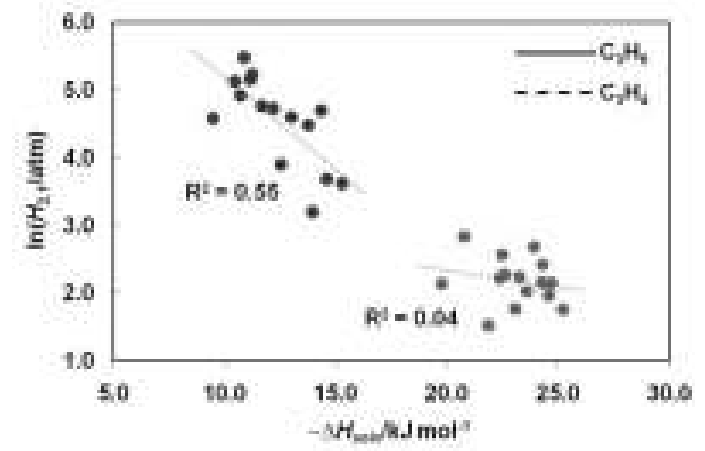

Figure 4. Solubility of propylene and propyne in correlation with the enthalpy of absorption (313 K).

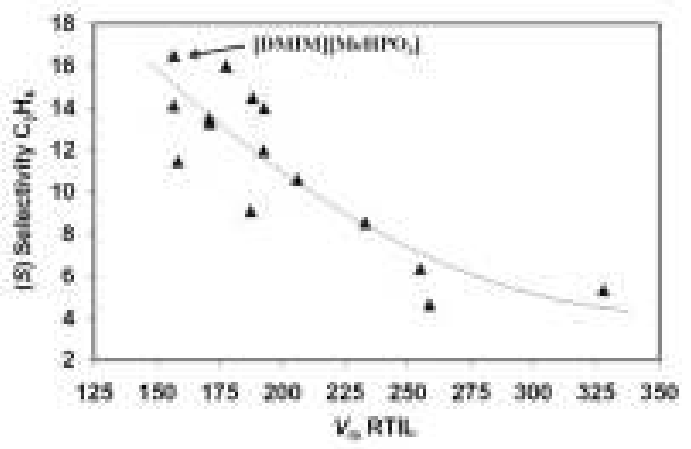

Figure 5. Ideal solubility selectivity of propyne over propylene (313 K): $S=H_{2.1}$ propylene $/ H_{2.1}$ propyne.

\section{Conclusions}

A series of RTILs with various basicities were evaluated for the potential application of propyne separation from propylene. From the solubility measurements, molecular modeling, and thermodynamic analysis, it is found that propylene solubility is mostly controlled by non-bonding, weak interactions, such as van der Waals interaction. The correlation between molar volume of RTILs and solubility of propylene indicates that greater RTIL's size leads to higher propylene solubility.

Meanwhile, a trade-off between specific (hydrogen bonding) and non-specific 
bondings may determine the propyne solubility in RTIL. Specifically, the hydrogen bonding takes place in the vicinity of anion moiety, between the most acidic proton of propyne and the proton acceptor atom in the anion. Therefore, to achieve greater propyne absorption selectivity, a RTIL with smaller size containing basic anion (to facilitate the hydrogen bond formation) should be employed.

\section{Acknowledgements}

This project is funded by a grant (AC3101 and 2009K000694) from Carbon Dioxide Reduction \& Sequestration Research Center, one of the 21st Century Frontier Programs funded by the Ministry of Science and Technology of Korean government and Kolon Industries Co.

\section{References}

Arce, A.; Earle, M. J.; Rodriguez, H.; Seddon, K. R.; Soto, A., 1-Ethyl-3-methylimidazolium bis $\{$ (trfluoromethyl)sulfonyl\}amide as solvent for the separation of aromatic ad aliphatic hydrocarbons by liquid extraction-extension to $C_{7^{-}}$and $C_{8}$-fractions, Green Chemistry, 2008, Vol. 10, 1294-1300.

Bos, A. N. R.; Westerterp, K. R., Mechanism and kinetics of the selective hydrogenation of ethyne and ethane, Chemical Engineering and Processing, 1993, Vol. 32, 1-7.

Camper, D.; Becker, C.; Koval, C.; Noble, R., Low pressure hydrocarbon solubility in room temperature ionic liquids containing imidazolium rings interpreted using regular solution theory, Industrial \& Engineering Chemistry Research, 2005, Vol. 44(6), 19281933.

Camper, D.; Bara, J.; Koval, C.; Noble, R., Bulkfluid solubility and membrane feasibility of Rmim-based room-temperature ionic liquids, Industrial \& Engineering Chemistry Research, 2006, Vol. 45(18), 6279-6283.

Downie, N. A., Industrial Gases, Kluwer Academic Pub., New York, 2002, 123.
Han, X.; Armstrong, D. W., Ionic liquids in separations, Accounts of Chemical Research, 2007, Vol. 40(11), 1079-1086.

Holbrey, J. D.; Reichert, W. M.; Swatloski, R. P.; Broker, G. A.; Pitner, W. R.; Seddon, K. R.; Rogers, R. D., Efficient, halide free synthesis of new, low cost ionic liquids: 1,3dialkylimidazolium salts containing methyland ethyl-sulfate anions, Green Chemistry, 2002, Vol. 4, 407-413.

Huang, W.; McCormick, J. R.; Lobo, R. F.; Chen, J. G., Selective hydrogenation of acetylene in the presence of ethylene on zeolite-supported bimetallic catalysts, Journal of Catalysis, 2007, Vol. 246, 40-51.

Jacquemin, J.; Costa Gomes, F.; Husson, P.; Majer, V., Solubility of carbon dioxide, ethane, methane, oxygen, nitrogen, hydrogen, argon, and carbon monoxide in 1-butyl-3methylimidazolium tetrafluoroborate between temperatures $238 \mathrm{~K}$ and $343 \mathrm{~K}$ and at pressures close to atmospheric, Journal of Chemical Thermodynamics, 2006, Vol. 38, 490-502.

Kuhlmann, E.; Himmler, S.; Giebelhaus, H.; Wasserscheid, P., Imidazolium dialkylphosphate-a class of versatile, halogenfree and hydrolytically stable ionic liquids, Green Chemistry, 2007, Vol. 9, 233-242.

Palgunadi, J.; Kang, J. E.; Nguyen, D. Q.; Kim, J. H.; Min, B. K.; Lee, S. D.; Kim, H.; Kim, H. S., Solubility of $\mathrm{CO} 2$ in dialkylimidazolium dialkylphosphate ionic liquids, Thermochimica Acta, 2009, Vol. 494, 94-98.

Pârvulescu, V.I.; Hardacre, C., Catalysis in ionic liquids, Chemical Reviews, 2007, Vol. 107(6), 2615-2665.

Roberts, L. R., Encyclopedia of Chemical Process and Design, Vol. 1, Marcel Dekker Inc., New York, 1976, 363-382.

Weissermel, K.; Arpe, H. -J., Industrial Organic Chemistry, 4th Ed., Wiley-VCH, Weinheim, Germany, 2003, 91-98. 